\title{
Pelatihan Pembuatan Herbarium Sebagai Pengayaan Media Pembelajaran Ipa-Biologi Bagi Guru Smp Mgmp Ipa Di Kecamatan Way Tenong Kabupaten Lampung Barat
}

\author{
Tundjung Tripeni Handayani ${ }^{1}$, Sumardi ${ }^{1}$, dan Christina Nugroho Ekowati ${ }^{1}$ \\ 1) Jurusan Biologi Fakultas Matematika dan Ilmu Pengetahuan Alam Universitas Lampung \\ Jl. Soemantri Brojonegoro No. 1 Gedung Meneng Bandar Lampung 35144 \\ Email: sumardi.1965@fmipa.unila.ac.id Email : ecoli.lacto@gmail.com
}

\begin{abstract}
Abstrak
Materi pelajaran IPA di SMP mengandung pelajaran Biologi dan Fisika. Sedangkan sebagian besar guru SMP IPA di Kecamatan Way Tenong bukan dari latar belakang Pendidikan Biologi, namun tetap harus dapat mengajarkan materi tentang Biologi. Oleh karena itu dalam mengajar pelajaran IPA tersebut para guru sering menemui kendala, yaitu kesulitan dalam menjalankan praktikum dan mendapatkan bahan yang sesuai. Tujuan pelaksanaan Pelatihan dilakukan dengan pendekatan pemberian teori dan praktek langsung membuat herbarium. Pelatihan diikuti oleh 31 orang guru SMP MGMP IPA Lampung Barat. Sebelum pelatihan dilaksanakan, pengetahuan peserta tentang pembuatan herbarium sebesar 45\%. Setelah pelatihan pengetahuan peserta meningkat menjadi 92\%. Dengan demikian terjadi peningkatan pengetahuan sebesar 47\%. Hasil Pelatihan, berupa herbarium dapat digunakan sebagai media pembelajaran bidang IPA khususnya Biologi.
\end{abstract}

Kata kunci: herbarium, guru smp, pembelajaran

PENDAHULUAN

Dalam Peraturan Menteri Pendidikan dan Kebudayaan Republik Indonesia Nomor 35 Tahun 2018 menekankan pada pemahaman tentang lingkungan dan alam sekitar beserta kekayaan yang dimilikinya, perlu dilestarikan dan dijaga dalam perspektif bidang IPA (biologi, fisika, dan kimia). Guru merupakan salah satu ujung tombak dalam mewujudkan Permen 35 tahun 2018 tersebut. Proses pembelajaran yang berkualitas, harus didukung dengan kopetensi guru. Guru dituntut untuk memiliki kekayaan materi ajar, terutama dalam memanfaatkan lingkungan sebagai sumber belajar. Mata pelajaran IPA terdiri dari materi fisika dan biologi.

Dilain pihak, sebagian besar guru SMP IPA di Kecamatan Way Tenong bukan dari latar belakang Pendidikan Biologi, namun harus mengajarkan materi tentang Biologi. Oleh karena itu dalam mengajar Biologi para guru sering menemui kendala, yaitu tidak trampil dalam praktikum dan kesulitan mendapatkan bahan yang sesuai. Untuk menanggulangi hal

$$
\text { Pendidikan } 806
$$


tersebut guru dapat menggunakan media pembelajaran guna menarik minat siswa terhadap materi pembelajaran yang disajikan, untuk meningkatkan pemahaman siswa terhadap materi yang disajikan (Susilo 2015; Majid dan Sunarti, 2013). Media pembelajaran dapat memperjelas penyajian pesan dan informasi sehingga dapat memperlancar dan meningkatkan proses dan hasil belajar (Arsyad 2011; Sukiman ,2012). Media belajar biologi dapat berupa objek awetan antara lain herbarium. Herbarium adalah pengawetan koleksi spesimen tumbuhn yang diawetkan, tujuannya untuk membantu identifikasi tumbuhan.(_Nisaa, dkk. 2019). Hasil penelitian Afifah dkk (2014), menunjukkan pembelajaran menggunakan media herbarium dapat meningkatkan pemahaman siswa sebesar $83,08 \%$ dibandingkan yang tanpa media herbarium yaitu sebesar 72,23\%. Demikian halnya penelitian Sulistyarsi, (2010) bahwa efektivitas pembelajaran IPA terpadu menggunakan herbarium dan insektarium sebagai suplemen media pembelajaran lebih tinggi dibandingkan tanpa herbarium dan insektarium pada tema klasifikasi makhluk hidup kelas 7.

Sasaran dari pengabdian adalah guru-guru IPA SMP MGMP Lampung Barat. Tujuan pengadian ini adalah untuk memberikan pemahaman tentang pembuatan herbarium dengan memberikan teori dan praktikum.

\section{METODE}

Tahapan yang ditempuh dalam melaksanakan pengabdian ini meliputi empat macam kegiatan, yaitu: 1) Kegiatan Ceramah dan Demonstrasi pembuatan herbarium. Kegiatan ini untuk memberikan dasar pemahaman dan pengetahuan tentang definisi herbarium, jenis herbarium, proses pembuatannya. Herbarium memiliki beberapa jenis yaitu herbarium kering dan herbarium basah.(Pujiati, 2017). 2). Kegiatan Diskusi yang yang berlangsung bersamaan pada saat ceramah berlangsung. 3). Kegiatan Praktik pembuatan herbarium dapat dilakukan dengan suatu cara atau metode yang sederhana. Metode tersebut dibuat dengan peralatan dan bahan yang mudah diperoleh sehingga dapat dilakukan oleh guru IPA SMP di kecamatan Way Tenong Kabupaten Liwa. Material herbarium yang diambil harus memenuhi tujuan pembuatan herbarium, yakni untuk identifikasi dan dokumentasi. Dalam pekerjaan identifikasi tumbuhan diperlukan ranting, daun, kuncup, kadang-kadang bunga dan buah, dalam satu kesatuan. Material herbarium yang lengkap mengandung ranting, daun muda dan tua, kuncup, bunga muda dan tua yang mekar, serta buah muda dan tua. Material herbarium dengan bunga dan buah jauh lebih berharga dan biasa disebut herbarium fertil, sedangkan material herbarium tanpa bunga dan buah disebut herbarium steril. Kemudian spesimen disemprot lagi dengan alkohol, satu persatu diletakkan dalam lipatan kertas koran dengan mengatur posisinya sedemikian rupa hingga posisinya rapi. Kemudian spesimen disusun dalam apitan kertas kardus atau tripleks yang berukuran $32 \mathrm{x}$ $42 \mathrm{~cm}$ dengan susunan kardus-spesimenkardusspesimen dan seterusnya sampai maksimal 50 spesimen. Pastikan bahwa etiket gantung masih dapat dibaca dengan jelas pada saat dimasukkan. Kemudian spesimen diapit dan diikat, untuk selanjutnya dikeringkan dengan panas matahari atau oven. Lama penegeringa tergantung jenis tumbuhan, bila menggunakan oven digunakan suhu $60-80^{\circ} \mathrm{C}$ selama $46-48$ jam. (Pudjoarinto, 1996). 4). Kegiatan Evaluasi. Pada kegiatan ini dilakukan dua macam evaluasi yaitu evaluasi awal, dan evaluasi akhir. Evaluasi awal bertujuan untuk mengetahui pemahaman peserta pelatihan mengenai metode koleksi dan pembuatan insektarium sebelum pelatihan dilakukan. Sedangkan Evaluasi akhir bertujuan untuk mengetahui pemahaman peserta mengenai materi yang sudah diberikan setelah pelatihan dilakukan (Grondlund dan Linn. 1990) 


\section{HASIL DAN PEMBAHASAN}

Pelatihan diikuti oleh 31 orang guru SMP MGMP IPA Lampung Barat. Pelaksanaan di SMP Negeri 1 Way Tenong pada hari Selasa tanggal 3 Maret 2020. Berdasarkan hasil evaluasi awal dan evaluasi akhir, diperoleh keningkatan pemahaman peserta tentang pembuatan herbarium. Hal ini dapat terlihat dari Gambar 1.

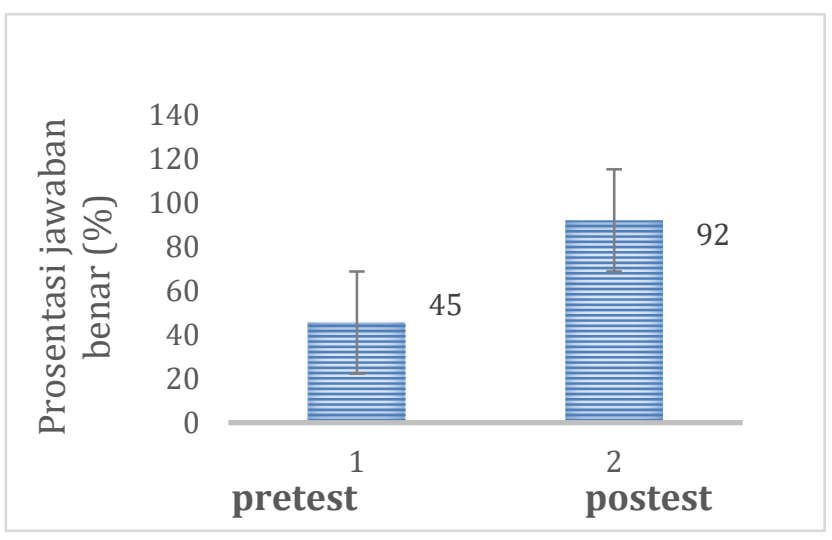

Gambar 1. Prosentase pengetahuan peserta tentang herbarium Sebelum dilakukan pelatihan hasil pretest $45 \%$ jawaban benar, dan setelah dilakukan pelatihan hasil postes menjadi $92 \%$ jawaban benar.

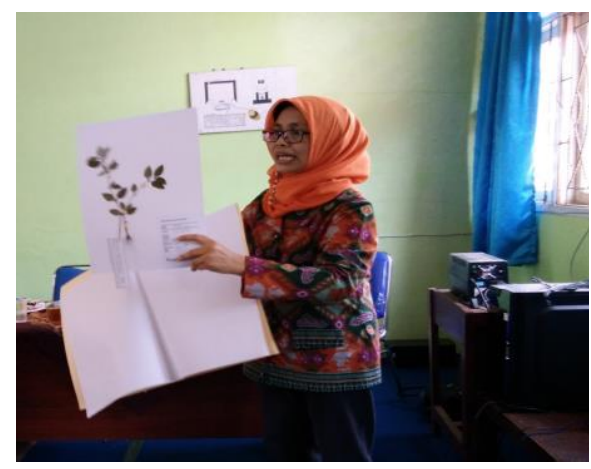

Gambar 2. Penjelasan pembuatan herbarium oleh narasumber Tundjung Tripeni Handayani.

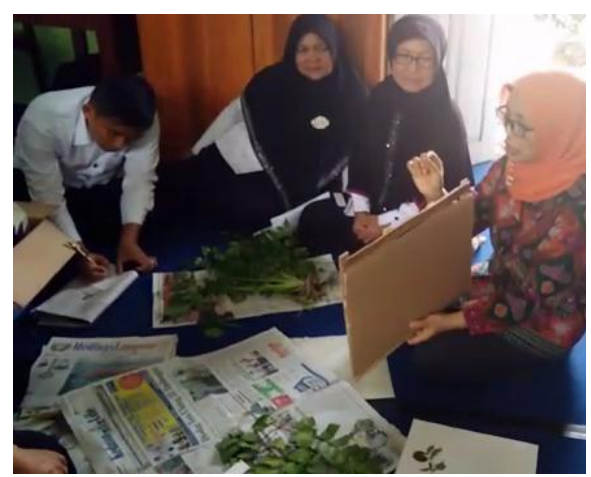

Gambar 2. Peserta antusias mengikuti pelatihan pembuatan herbarium oleh narasumber Tundjung Tripeni Handayani.

Peserta pelatihan mengenakan baju putih. Narasumber mengenakan baju batik 
Sebelum dilakukan pemberian materi, hasil pretest menunjukkan bahwa pengetahuan mereka tentang herbarium masih rendah (45\%). Setelah dilakukan pengajaran dan praktikum pembuatan herbarium, kemudian mereka memiliki pengetahuan herbarium tinggi (92\%). Pengajaran dan praktikum sangat memberikan dampak yang besar bagi penambahan pengetahuan. Peserta dapat langsung mengetahui hal-hal yang membuat keberhasilan dan kegagalan dalam pembuatan herbarium.

Peserta sangat antusias dengan kegiatan tersebut dan sangat mengharapkan ada kegiatan lanjutannya. Dengan demikian maka keberlanjutan kegiatan pelatihan untuk guru IPA SMP di kabupaten Lampung barat sangat ditunggu.

\section{KESIMPULAN}

Peserta sangat antusias dengan kegiatan pembuatan herbarium. Bagi guru yang berlatar belakang Biologi, kegiatan ini merupakan penyegaran Kembali. Sedangkan bagi guru yang berlatar belakang di luar bidang Biologi merupakapan masukan yang sangat berharga. Secara keseluruhan, sebelum pelatihan dilaksanakan, pengetahuan peserta tentang pembuatan herbarium sebesar $45 \%$. Setelah pelatihan pengetahuan peserta meningkat menjadi 92\%. Dengan demikian terjadi peningkatan pengetahuan sebesar $47 \%$. Dengan melihat kegiatan tersebut sebaiknya kepada pihak terkait agar sebaiknya melaksanakan kegiatan pelatihan kepada guru secara rutin.

\section{REFERENSI}

Afifah, N., Sudarmin, T. Widianti. (2014). Efektivitas Penggunaan Herbarium Dan Insektarium Pada Tema Klasifikasi Makhluk
Hidup Sebagai Suplemen Media Pembelajaran Ipa Terpadu Kelas Vii Mts Unnes Science Education Journal 3 (2) ::494-501

Arsyad,A. (2011). MediaPembelajaran. Jakarta: Rajawali Pres

Grondlund \& Linn. (1990). Measurement and Evaluation in Teaching. Sixth Edition. New York : Macmillan Publishing Company.

Majid, D. \& Sunarti, M. (2013). Pengembangan Herbarium Pada Siswa Madrasah Aliyah Media Pembelajaran Kota Ternate. Jurnal Bioedukasi 2(1): 196

Nisaa, Ranti An Lestari, Suci, \& Astuti, Y. (2019). Pelatihan Pembuatan Herbarium Sebagai Salah Satu Pengembangan Media Pembelajaran Biologi Berbasis Lingkungan di SMA Muhammadiyah 1 dan 2 Tangerang. Jurnal Pengabdian Masyarakat MIPA dan Pendidikan MIPA, 3 ( 1).

Pudjoarinto, A. 1996. Teknik Herbarium dan Pengelolaan Herbarium.Makalah pada Lokakarya Taksonomi Tumbuhan. HEDS PROJECT - Universitas Bengkulu

Pujiati, MA. (2017). Seni Membuat Herbarium. Solo Tiga Ananda.

Sukiman. (2012). Pengembangan Media Pembelajaran. Yogyakarta: Pustaka Insan Madani

Sulistyarsi,A. 2010. Penggunaan Media Herbarium dan Insectarium dalam Pembelajaran Biologi untuk Meningkatkan Hasil Belajar Siswa. Jurnal Pendidikan, 2(1): 3-14.

Susilo, M. J. (2015). Analisis Kualitas Media Pembelajaran Insektarium dan Herbarium untuk Mata Pelajaran Biologi Sekolah Menengah. Jurnal Bioedukatika 3(1): 10-15. 